Document downloaded from:

http://hdl.handle.net/10251/36256

This paper must be cited as:

Morata, T.; Sospedra, J.; Falco Giaccaglia, SL.; Rodilla Alama, M. (2012). Exchange of nutrients and oxygen across the sediment-water interface below a Sparus aurata marine fish farm in the north-western Mediterranean Sea. Journal of Soils and Sediments. 12(10):1623-1632. doi:10.1007/s11368-012-0581-2.

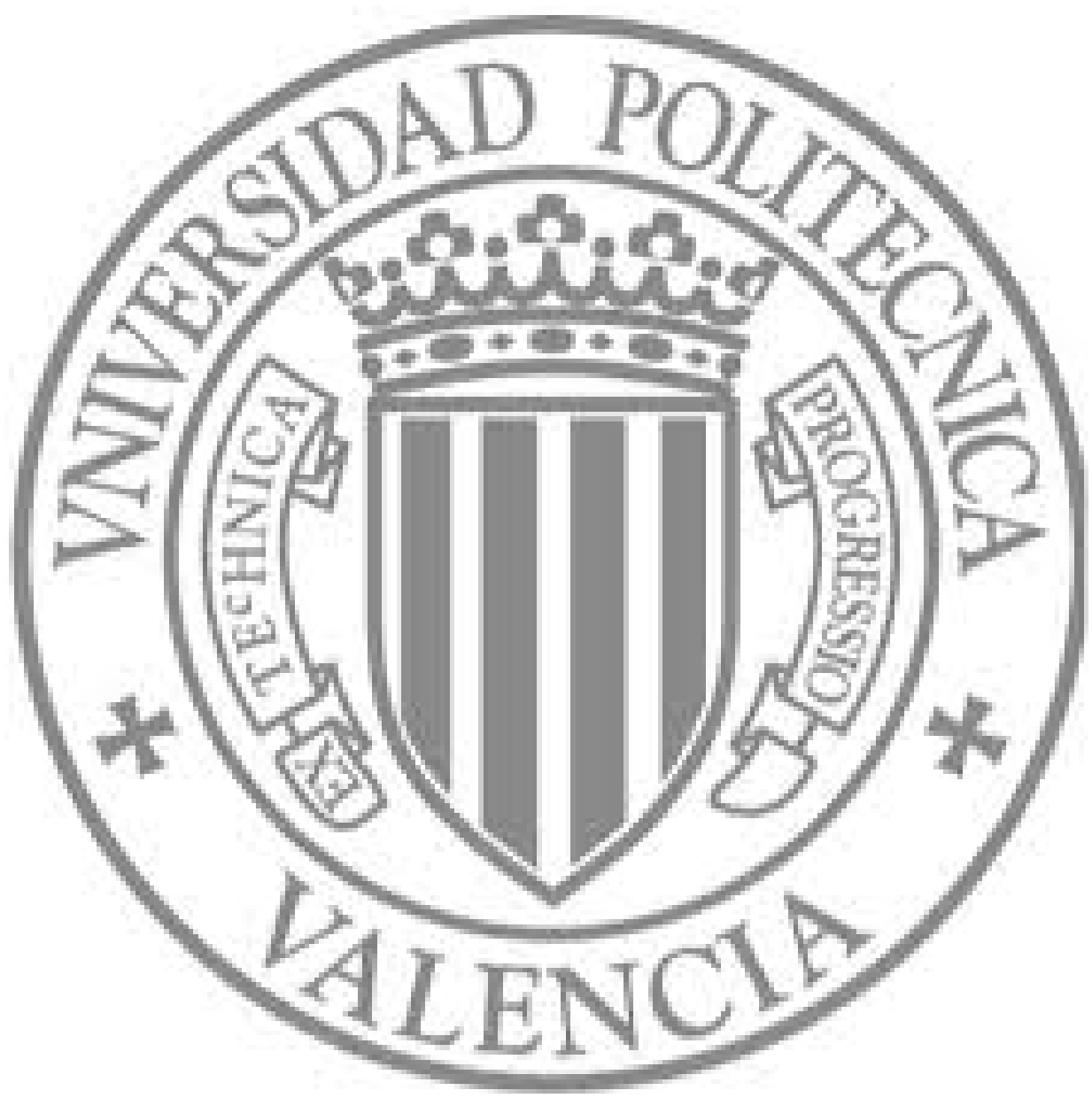

The final publication is available at

http://dx.doi.org/10.1007/s11368-012-0581-2

Copyright Springer Verlag (Germany) 


\title{
Exchange of nutrients and oxygen across the sediment-water interface below a Sparus aurata marine fish farm in the north-western Mediterranean Sea
}

\author{
Tania Morata, Javier Sospedra, Silvia Falco \& \\ Miguel Rodilla
}

Institut d’Investigació per a la Gestió Integrada de Zones Costaneres (IGIC), Universitat Politècnica de València, C/Paranimf, 1, 46730 Grau de Gandia, València, Spain

J Soils Sediments (2012) 12:1623-1632

DOI 10.1007/s11368-012-0581-2 


\begin{abstract}
Purpose This study analyzes the effects of aquaculture activities in open seawater in the north-western coastal waters of the Mediterranean Sea. It is the first of its kind to be based on benthic flux data gathered in situ below fish farms for this particular area.
\end{abstract}

Materials and methods Samples were collected on four sampling campaigns over a 1-year cycle under a Sparus aurata fish farm facility where benthic fluxes were measured in situ using light and dark benthic chambers. Bottom water and sediment samples were also collected. Data were compared to those for a nearby control station.

Results and discussion Significant differences were found (ANOVA, $p<0.05)$ between concentrations of organic matter $(\mathrm{OM})$, total phosphorus and redox potentials in sediments located under the cages and those of the control station. The consumption of dissolved oxygen (DO) by sediment and positive ammonium $\left(\mathrm{NH}_{4}{ }^{+}\right)$fluxes was stimulated by $\mathrm{OM}$ content, with correlations of $r=-0.60(p<0.01)$ and $r=0.70(p<0.01)$, respectively. The OM content of sediments was found to be consistently higher under the cages than at the control station, with the highest value $(1.8 \pm 0.7 \%)$ under the cages observed during the early summer; values of DO and $\mathrm{NH}_{4}{ }^{+}$fluxes were $64 \pm 17$ and $12.7 \pm 1.0 \mathrm{mmol} \mathrm{m}^{-2}$ day ${ }^{-1}$, respectively. $\mathrm{PO}_{4}{ }^{3-}$ fluxes were consistently higher in the fish farm sediments (between 0.58 and $0.98 \mathrm{mmol}$ $\mathrm{m}^{-2}$ day $\left.{ }^{-1}\right)$ than those observed at the control station. Nitrate $\left(\mathrm{NO}_{3}{ }^{-}\right)$fluxes were found to be consistently negative due to denitrification occurring in the sediments and were related to the concentration of $\mathrm{NO}_{3}^{-}$in bottom waters $(r=0.92, p<0.01)$. Si fluxes were shown to be associated with water temperature $(r=0.59, p<0.05)$.

Conclusions The results imply that sediments located below cages accumulate organic matter originating from aquaculture activities, especially 
during summer months when this activity increases. Sediments undergo biogeochemical changes that mainly affect fluxes of $\mathrm{DO}, \mathrm{NH}_{4}{ }^{+}$and soluble reactive phosphorus, although these do not seem to have a significant impact on the quality of the water column due to the hydrodynamic characteristics of the area.

Keywords Aquaculture impacts. Benthic. Fish farm. Fluxes. Sediment.

\section{Introduction}

World aquaculture production increased dramatically from $0.6 \times 10^{6} \mathrm{t}$ in 1950 to $68.4 \times 10^{6} \mathrm{t}$ in 2008 . Spain's aquaculture production is the highest of all EU member countries and was 249,070 t in 2008 (19.5 \% of total EU production); followed by France and Italy (APROMAR 2010). It is a growing economic activity which unfortunately brings with it environmental consequences (Belias et al. 2007; Borja et al. 2009).

There is growing concern in many countries, both among citizens and the scientific community, regarding the sustainability of this growing industry (Hargrave 2005). The magnitude of its ecological impact depends on the physical and oceanographic conditions of the fish farm site, water temperature and ecosystem absorption capacity. In addition to this, fish farm management and size, cultivation density, duration of cultivation operations, fish feed digestibility and fish health are all significant factors that need to be taken into account (Molina and Vergara 2005).

Studies of the environmental effects of aquaculture activities have focused on a number of aspects, including: changes occurring in the water itself (Maldonado et al. 2005) and in the sediment layers of fish farm facilities Karakassis et al. 1998; Aksu and Kocatas 2007); disturbances in Posidonia oceanica meadows (Pergent-Martini et al. 2006); anoxic conditions of the sediment layer below cages Hargrave et al. 1997); and the influence of current velocities (Black and McDougall 2002). Some studies have analysed 
metals and pigments found in sediments as well as bacteria and multiple stable isotopes as indicators of environmental impact (Mazzola et al. 2000; Kaymakci et al. 2010). Others have focused on the environmental impact of aquaculture activities on nutrients and plankton (Neofitou and Klaoudatos 2008); on nutrients and benthic community structure (Mazzola et al. 2000; Yucel-Gier et al. 2007); and on the geochemistry of sediments and benthic organisms Mazzola et al. 2000).

The enrichment in organic matter produced in the sediments below cages causes high rates of decomposition, which can modify the quality of the water around the facility. This can lead to a decrease in oxygen in the water column, promote eutrophication and turn the sediments anoxic, with the result that the organic matter decomposes anaerobically. It can also seriously affect the structure of the benthic community (Jackson et al. 2004). Sediment plays a crucial role in the cycling of nutrients and can operate as the main source of nutrients in the water column, especially in coastal ecosystems (Warnken et al. 2002). A greater understanding of the above processes would help to predict impacts and adopt practices in aquaculture activity geared towards a sustainable use of the marine environment. By measuring oxygen and nutrient fluxes, it is possible to identify the main mechanisms in the mineralisation process and quantitatively determine the importance of sediments in the global cycles of nutrients on fish farms (Riise and Roos 1997).

Thus, this study should be seen in the context of the widespread preoccupation which exists with the release of waste from aquaculture and its potential to cause great harm to the ecosystem through changes in the nutrient load. More specifically, the study focuses on the effects of gilthead sea bream (Sparus aurata) farming activities on benthic metabolism over a 1-year farming cycle. These activities involve the use of floating cages located in 
open seawater in the north-western waters of the Mediterranean Sea. Oxygen and nutrient fluxes at the sediment-water interface were determined via in situ incubations using benthic chambers. All the data were compared with that collected at a control station.

It is worth pointing out that at the international level, there have been few in situ studies into benthic fluxes at fish farms (e.g. Holby and Hall 1991, 1994; Hall et al. 1992; Freitas et al. 2008; Ferrón et al. 2009), or ex situ studies (e.g. Heilskov and Holmer 2001; Nizzoli et al. 2007). Just one study of north-western Mediterranean waters has been completed to date and this involved ex situ experiments (Belias et al. 2007).

\section{Materials and methods}

\subsection{Study area}

The study area is located in the north-western waters of the Mediterranean Sea, off the coastal town of Burriana (Spain), on the site of an intensive fish farm (UTM X: 752170; UTM Y: 4414096) located about 2 km from the coast at a depth of $19 \mathrm{~m}$. The area is characterised by sandy sediments. The fish farm comprises 15 cages, and all measurements were taken from an area below a cage located at the centre of the fish farm. This farm produces $500 \mathrm{t}$ annually and measurements were taken below a cage with a biomass of between 30 and $47 \mathrm{t}$. The sea breams were fed on commercial feed (conversion factor, 1.8 to 2), which was unequally distributed throughout the year as the feed rate varied according to temperature.

\subsection{Sampling and sampling points}

Measurements were taken from two sampling points: the first was located below a fish farm cage (I) and the other, which was used as a control area (C), was located $100 \mathrm{~m}$ north of the fish farm, up-current from dominant 
sea currents. Samples were collected during four sampling campaigns: the first in autumn (25 November 2008, I-1; 01 December 2008, C-1); the second in winter (23 February 2009, I-2; 28 February 2009, C-2); the third in spring (28 April 2009, I-3; 02 May 2009, C-3); and the fourth in early summer (17 June 2009, I-4; 19 June 2009, C-4). Control station sediments were similar to those found below the fish farm cages. The control station was not influenced by nutrients released by the fish farm activities and the 100-m distance was deemed sufficient as various authors (e.g. Karakassis et al. 1998; Yucel-Gier et al. 2007; Borja et al. 2009) have shown that the environmental effects of fish farm activities are limited to areas immediately beneath the cages.

\subsection{Benthic chamber experiments and analysis}

To study nutrient and oxygen fluxes at the sediment-water interface, measurements were taken in situ using benthic chambers, similar to those used by Freitas et al. (2008). Light and dark chambers were used for each incubation, with three replicate samples being taken for each chamber type to minimise the effects of spatial heterogeneity. The measurements were taken using semi-spherical methacrylate chambers with a diameter of $40 \mathrm{~cm}$ and a volume of $16.7 \mathrm{l}$, covering a sediment surface area of $0.125 \mathrm{~m}^{2}$. The chambers contained a manual stirrer to minimise concentration gradients (Niencheski and Jahnke 2002).

The chambers were placed in the sediment manually by scuba divers, and the total incubation period was $6 \mathrm{~h}$. Samples of water were taken from inside the chambers every $2 \mathrm{~h}$ using 60-ml plastic syringes inserted through openings controlled by a valve. Ammonium $\left(\mathrm{NH}_{4}{ }^{+}\right)$, nitrates $\left(\mathrm{NO}_{3}{ }^{-}\right)$, soluble reactive phosphorus $\left(\mathrm{PO}_{4}{ }^{3-}\right)$, silicate ( $\mathrm{Si}$ ) and dissolved oxygen (DO) concentrations were analysed. Benthic fluxes were estimated from the slope of a linear regression of the time series results and the chamber volume (Niencheski and Jahnke 2002) and Eq. (1), as used by Nizzoli et al. (2007): 
$F=\left(C_{t}-C_{o}\right) \cdot(1(A \cdot t)) \cdot V \cdot 24$

where $\mathrm{F}$ (millimoles per square metre per day) is the estimated flow; $\mathrm{C}_{\mathrm{t}}$ and $\mathrm{C}_{0}$ (millimoles) are the final and initial concentrations obtained in the linear fit; A (square metre) is the area of incubation; t (hours) is the total incubation time; and V (l) is volume of incubated water.

\subsection{Bottom water and sediment}

At the start of each sampling day, the transparency of the water column was measured using a Secchi disk (Secchi depth), and salinity (Sal), $\mathrm{pH}$ and temperature (Temp) of bottom water were measured using a WTW Multi 340i multiparameter probe. Water samples were taken using a Niskin bottle at a depth of $0.5 \mathrm{~m}$ from the bottom to analyse DO and nutrients. Samples were also taken every $2 \mathrm{~m}$ from the water column to analyse for chlorophyll-a (chl-a).

Scuba divers visually inspected the sea bottom for signs of Beggiatoa spp. and phytobenthic assemblages. During each sampling session, three samples of unaltered sediment layers were taken from the fish farm and control area using corers with a length of $30 \mathrm{~cm}$ and an internal diameter of $6.5 \mathrm{~cm}$ in order to examine physical and chemical parameters such as redox potential (Eh), organic matter (OM), water content, porosity, granulometry and total phosphorus (TP). When the corers were brought up to the surface, their Eh was measured and $1 \mathrm{~cm}$ of sediment was removed from the uppermost layer of the sample for analysis of the various parameters.

\subsection{Parameters considered and analytical methods}

The DO samples were fixed immediately and analysed in situ using the Winkler iodometric method (Baumgarten et al. 1996). For the analysis of dissolved nutrients, the samples were filtered using a cellulose acetate 
membrane filter with a pore size of $0.45 \mu \mathrm{m}$. The $\mathrm{NH}_{4}{ }^{+}$was determined on the same day and the remaining samples were frozen for later analysis. The nutrients were analysed using the methods described by Aminot and Chaussepied (1983) and adapted by Baumgarten et al. (1996). The chl- $a$ was determined using the methodology described in APHA, AWWA and WEF (2005). The intensity of light at the bottom $\left(\mathrm{I}_{\mathrm{z}}\right)$ was calculated following Lorenti and De Falco (2004) using the Secchi depth and solar radiation data provided by the Valencian Institute of Agricultural Research. Sediment Eh was measured at a depth of $0.5 \mathrm{~cm}$ using a Crison PH25 potentiometer. Sediment water content was calculated as the difference between wet and dry weight and expressed as a percentage. Sediment porosity was determined according to Dell'Anno et al. (2002). To determine sediment TP, digestion was performed following Arocena and Conde (1999). OM was analysed using the combustion method (Dell'Anno et al. 2002). Granulometry was performed for the sediment samples using the Wentworth scale (Shepard 1954).

\section{Results}

\subsection{Bottom water and sediment}

Table 1 lists the values for DO, nutrients, salinity, $\mathrm{pH}$ and temperature of bottom water, Secchi depths and the I $\mathrm{z}$ values were calculated for the fish farm and the control station. The temperature varied between 12.9 ${ }^{\circ} \mathrm{C}$ in winter and $20.3{ }^{\circ} \mathrm{C}$ at the beginning of summer. Salinity ranged from 37.0 to $38.0 \%$. DO concentrations at the fish farm were found to be consistently lower than those observed at the control station. The highest concentration of $\mathrm{NH}_{4}^{+}$was observed in autumn at the fish farm, with a value of $3.1 \mu \mathrm{M}$, and the highest concentrations of $\mathrm{NO}_{3}{ }^{-}$were observed in autumn and winter. $\mathrm{PO}_{4}{ }^{3-}$ concentrations were very low and there were no great differences among the four sampling campaigns: the values oscillated 
between 0.10 and $0.26 \mu \mathrm{M}$. The maximum $\mathrm{Si}$ value of $5.4 \mu \mathrm{M}$ was found in the bottom water of the control station in the early summer.

No differences in transparency were found between the fish farm and the control station, except for a control station sample taken in early summer, which had a higher value and resulted in a greater $I_{z}$. As can be seen from Table 1 , the $I_{z}$ value was quite low except for the early summer sample just mentioned, which was $12.3 \mathrm{~W} \mathrm{~m}^{-2}$. In fact, the Iz below the cages may have been overestimated as Secchi depths were taken next to the cage and the shade they generated over the sediment was not taken into account.

Table 1 Parameters measured in bottom water of the fish farm (I) and the control station $(\mathrm{C})$ in the four sampling campaigns

\begin{tabular}{|c|c|c|c|c|c|c|c|c|}
\hline \multirow{2}{*}{ Parameters } & \multicolumn{2}{|c|}{ Autumn } & \multicolumn{2}{|c|}{ Winter } & \multicolumn{2}{|c|}{ Spring } & \multicolumn{2}{|c|}{ Early Summer } \\
\hline & I & $\mathrm{C}$ & I & $\mathrm{C}$ & I & $\mathrm{C}$ & I & $\mathrm{C}$ \\
\hline Temp $\left({ }^{\circ} \mathrm{C}\right)$ & 16.0 & 15.0 & 12.9 & 12.9 & 16.0 & 16.1 & 20.3 & 18.6 \\
\hline Sal (\%o) & 37.8 & 37.9 & 37.9 & 38.0 & 37.0 & 37.4 & 37.4 & 37.4 \\
\hline $\mathrm{pH}$ & 8.1 & 8.1 & 8.2 & 8.1 & 8.1 & 8.1 & 8.0 & 8.0 \\
\hline $\mathrm{DO}\left(\mathrm{mg} \mathrm{l}^{-1}\right)$ & 4.4 & 7.1 & 8.4 & 8.7 & 7.9 & 9.4 & 7.8 & 9.0 \\
\hline $\mathrm{NH}_{4}^{+}(\mu \mathrm{M})$ & 3.1 & 0.5 & 0.4 & $<0.1$ & $<0.1$ & $<0.1$ & 0.5 & 0.9 \\
\hline $\mathrm{NO}_{3}^{-}(\mu \mathrm{M})$ & 4.0 & 0.7 & 3.9 & 2.0 & 0.3 & 0.1 & 0.2 & 0.0 \\
\hline $\mathrm{PO}_{4}^{3-}(\mu \mathrm{M})$ & 0.23 & 0.13 & 0.12 & 0.11 & 0.22 & 0.26 & 0.10 & 0.10 \\
\hline $\mathrm{Si}(\mu \mathrm{M})$ & 2.6 & 1.7 & 2.1 & 2.9 & 1.8 & 2.0 & 1.1 & 5.4 \\
\hline Secchi depth (m) & 6.0 & 5.0 & 4.9 & 4.6 & 6.7 & 6.0 & 6.7 & 13.0 \\
\hline $\mathrm{I}_{\mathrm{z}}\left(\mathrm{Wm}^{-2}\right)$ & 0.2 & 0.2 & 0.2 & 0.1 & 1.0 & 0.6 & 2.4 & 12.3 \\
\hline
\end{tabular}

Both the fish farm and the control station were characterised by sandy sediments with a grain size mode of between 0.125 and $0.063 \mathrm{~mm}$ and an average grain size corresponding to very fine sand. At both locations, water content was approximately $25 \%$ and porosity was 0.46 . Differences were found only in the percentage of shell content $(12.1 \pm 4.0 \%$ under the fish 
farm and $0.3 \pm 0.2 \%$ at the control station). The value was 37 times higher under the cages due to anti-fouling activity (cleaning of cages).

Significant differences (ANOVA, $p<0.05$ ) were found between fish farm and control station sediments in OM content, TP concentrations and Eh measurements. In the four sampling campaigns, OM content and TP concentrations were found to be greater at the fish farm than at the control station (Fig. 1a, b). The highest OM content (1.8 $\pm 0.7 \%)$ and TP $(1,350 \pm 411$ $\left.\mathrm{mg} \mathrm{kg}^{-1}\right)$ and greatest negative values for Eh $(-207 \pm 90 \mathrm{mV})$ were found in the early summer samples taken from below cages. Reducing conditions were observed under the cages throughout the year; Eh values were found to be consistently negative and much lower than those observed at the control station (see Fig. 1c). Visual inspections did not reveal Beggiatoa spp.; however, microphytobenthic assemblages were observed in the control station sediments in the spring.

a)

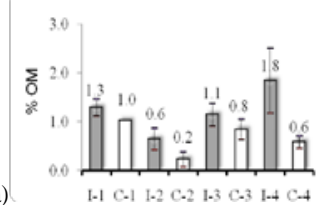

b)

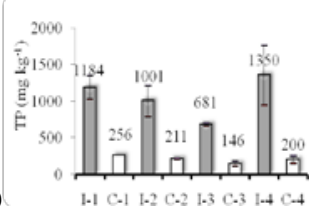

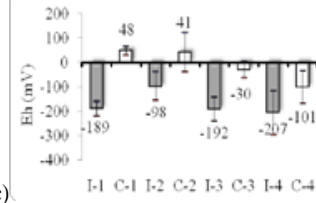

Fig. 1 a-c Values of organic matter (OM), total phosphorus (TP) and Eh in sediments under the fish farm (I) and the control station (C) in the four sampling campaigns.

\subsection{Benthic fluxes}

Analysis of all samples revealed no significant differences between the dark and light benthic chambers for the fluxes measured. In general, DO fluxes were negative (Fig. 2a), which indicates DO consumption by the 
sediment. These values were found to be more negative at the fish farm than at the control station, and the highest consumption value was found under the cages in the early summer (up to $-71 \pm 20 \mathrm{mmol} \mathrm{m}^{-2}$ day $^{-1}$ ). Significant differences (ANOVA, $p<0.05$ ) between the fish farm and the control station were only observed in spring and early summer. It was during these seasons when a positive flux was also observed in the light benthic chambers at the control station (up to $17 \pm 10 \mathrm{mmol} \mathrm{m}^{-2} \mathrm{day}^{-1}$, in spring). All the chambers showed positive fluxes in $\mathrm{NH}_{4}{ }^{+}$from the sediment to the water column (see Fig. 2b). Significant differences (ANOVA, $p<0.05$ ) were found between $\mathrm{NH}_{4}{ }^{+}$fluxes measured at the fish farm and at the control station in the autumn, spring and early summer. The latter sampling campaign showed the greatest differences, with the highest flux found under the fish farm (13.6 \pm 1.0 mmol m${ }^{-2}$ day $\left.^{-1}\right)$.

$\mathrm{PO}_{4}{ }^{3-}$ fluxes were generally positive, i.e. phosphorus from the sediment was released to the water column, and were consistently greater below the fish farm than at the control station (see Fig. 2c); however, significant differences were only found (ANOVA, $p<0.05$ ) in autumn and early summer. $\mathrm{NO}_{3}{ }^{-}$fluxes were negative, i.e. $\mathrm{NO}_{3}{ }^{-}$from the water column was consumed by the sediment. These fluxes were found to be more negative at the fish farm in autumn, winter and spring than those observed at the control station (see Fig. 2d), although significant differences (ANOVA, $p<0.05$ ) were only found in autumn. Si fluxes were positive (see Fig. 2e), except for the samples taken in winter at the control station, which showed negative fluxes in both the light and dark benthic chambers. Significant differences (ANOVA, $p<0.05$ ) between Si fluxes at the fish farm and control station were only observed in the winter. The highest and most positive Si fluxes were found in spring and early summer. 
Autumn

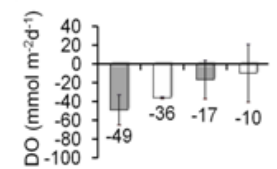

b)

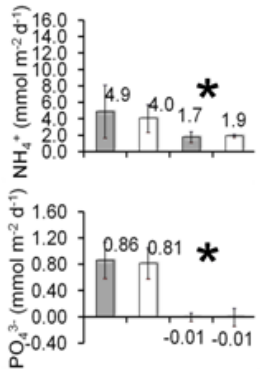

d)

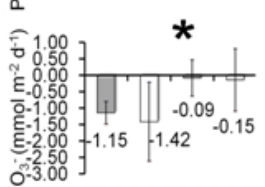

e)

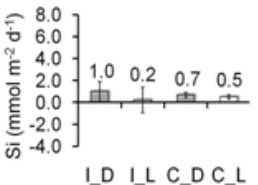

Winter
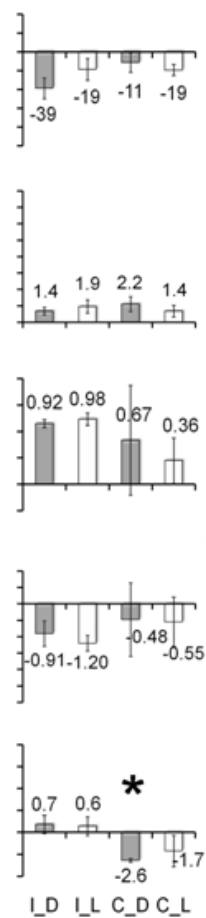

Spring
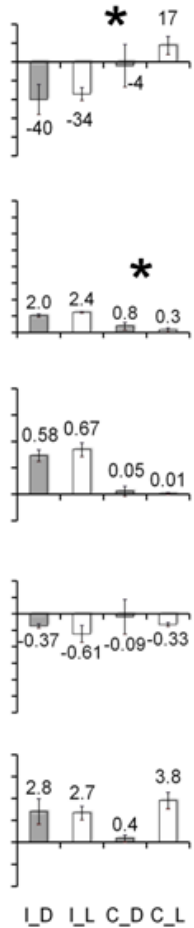
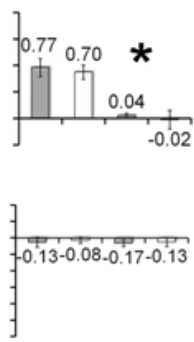

Early summer
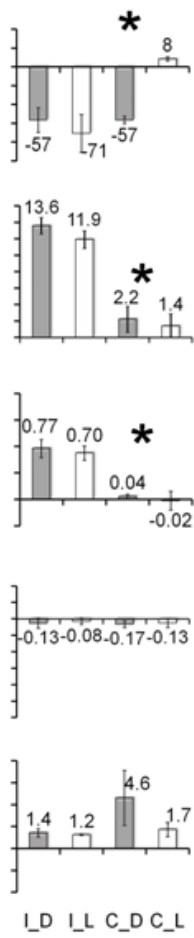

Fig. 2 Benthic fluxes of dissolved oxygen (DO), ammonium (NH4+), soluble reactive phosphorus $\left(\mathrm{PO}_{4}{ }^{3-}\right)$, nitrate $\left(\mathrm{NO}_{3}{ }^{-}\right)$and silicate $(\mathrm{Si})$ in dark (D) and light (L) chambers under the fish farm cage (I) and at the control station (C) in the four sampling campaigns. Asterisk: significant differences (ANOVA, $p<0.05$ ) between fish farm and control station.

\section{Discussion}

\subsection{Bottom water and sediment}

Water temperature varied according to season. The lower concentrations of DO observed at the fish farm compared to those at the 
control station may be attributable to the consumption of oxygen by fish respiration and the aerobic decomposition of OM. The higher concentrations of $\mathrm{NH}_{4}{ }^{+}$observed at the fish farm in autumn may have been caused by fish excretion (Dosdat 2001; Aksu and Kocatas 2007) and possible decomposition of OM. The differences in $\mathrm{NO}_{3}{ }^{-}$, which were found to be greater at the fish farm, were most likely due to oxidation of $\mathrm{NH}_{4}{ }^{+}$to form $\mathrm{NO}_{3}^{-}$(Dosdat 2001). The higher concentrations of $\mathrm{NO}_{3}{ }^{-}$in the Mediterranean in winter were also found by Maldonado et al. (2005). As P is a limiting nutrient in the Mediterranean (Siokou-Frangou et al. 2010), this may be the reason why we found lower concentrations of $\mathrm{P}$; these values are similar to those observed by Kaymakci et al. (2010). The highest concentration of Si at the sea bottom in summer was also observed by Kaymakci et al. (2010) and may be due to mineralization of biogenic Si accumulated at the sea bottom.

OM content was consistently higher under the cages than at the control station, a finding which is known to occur under fish farm cages located in open seawater (Mantzavrakos et al. 2007; Borja et al. 2009). OM in sediment mostly originates from non-ingested fish feed, either due to overfeeding or poorly managed diet or feeding regime. Accumulation of fish faeces, farmed fish mortality and cage cleaning may also increase OM in the sediment (Molina and Vergara 2005). The highest OM content was found in early summer under the cages owing to the higher temperatures, which increased the metabolism of the fish and, consequently, their rate of feeding. This led to greater losses in fish feed and greater rates of excretion. OM values observed in this study were similar to those seen at other fish farms (Sakamaki et al. 2006;Nizzoli et al. 2007) although Mantzavrakos et al. (2007)observed higher values in OM in the Mediterranean Sea.

In this study, TP in the sediment below the cages was consistently higher than at the control station, which is in line with the findings of 
Karakassis et al. (1998). The highest concentrations were found in summer, as was also observed by Mantzavrakos et al. (2007). All of the above values, along with those observed for OM, were due to the increase in solid waste originating from increased production, typical of the season. TP concentrations in sediments under Mediterranean Sea fish farms observed in other studies (e.g. Karakassis et al. 1998) were of a similar order of magnitude to our results; however, Mantzavrakos et al. (2007) found TP concentrations to be lower.

On the basis of the Eh measurements, we found sediments under the cages to be consistently more negative, with the greatest negative value observed in early summer possibly due to the higher OM content, as this measurement is highly correlated to OM content $(r=-0.70, p<0.01)$ and TP ( $r=-0.79, p<0.01$; Table 2). Reducing conditions in fish farm sediments were found in other studies (e.g. Karakassis et al. 1998; Ferrón et al. 2009).

The study illustrates the effects that aquaculture activity has on the sediment in the proximity of fish farms. The sediment experiences an increase in $\mathrm{OM}$ and $\mathrm{TP}$ content, which at the same time become more reducive. It is important for companies and the competent environmental authorities to take into account the changes in aquaculture activity throughout the year resulting from changes in the prevailing water temperature. In addition to the general effect on the sediments and hence the environment, there are also seasonal changes which cause an increase in aquaculture activity and thus have a greater impact. The amount of activity also affects the parameters measured in the bottom water, but since the farm facility is close to the open sea, the water is constantly being refreshed, and thus, the differences are not as pronounced as the parameters measured in the sediments. 


\subsection{Benthic fluxes}

No significant differences were found between dark and light benthic chambers for any of the fluxes measured, which can be explained by the fact that $I_{z}$ values were close to zero for nearly all the samples taken, except for an early summer sample at the control station which was $12.3 \mathrm{~W}$ $\mathrm{m}^{-2}$. The low rate of primary production seen at a depth of $19 \mathrm{~m}$, therefore, did not significantly influence flux estimation. The negative fluxes of DO indicate that the sediments consumed oxygen from the water column in the case of the dark benthic chambers. This can be explained by the aerobic mineralization of $\mathrm{OM}$ in which heterotrophic microorganisms use oxygen as the terminal electron acceptor. In the light benthic chambers, the majority of fluxes were found to be negative, which indicates that the consumption of oxygen by mineralization was higher than that which could have been released as a result of primary production.

Positive values for DO fluxes were measured only in spring and at the beginning of summer at the control station. Microphytobenthic assemblages were observed in the spring in this area as well as in the early summer, and I z was greater see Table 1). DO consumed by the sediments was generally more negative under the fish farm cages than at the control station due to the higher OM content of the fish farm (r00.60, p<0.01) (see Table 2). The oxygen consumption of the sediment below the cages showed an increase over the control station of between $13 \mathrm{mmol} \mathrm{m}^{-2} \mathrm{day}^{-1}$ in the winter and approximately $42 \mathrm{mmol} \mathrm{m}^{-2}$ day $^{-1}$ in both the spring and early summer. The maximum value for sediment consumption of DO was observed in the early summer under the cages, co-occurring with higher bottom water temperatures $\left(20^{\circ} \mathrm{C}\right)$, higher rates of feeding and higher OM content found in the sediment. These conditions were similar to those observed by Nizzoli et al. (2007) and Ferrón et al. (2009). Other studies that examined DO fluxes on 
aquaculture facilities obtained results similar to those seen in this study (e.g. Ferrón et al. 2009) or lower fluxes (e.g. Nizzoli et al. 2007; Freitas et al. 2008). We consider that sediment oxygen demand is an index which can be used to estimate the benthic regeneration rate, as well as being a good parameter for assessing how well this industrial activity is being managed. DO fluxes were also found to be inversely proportional to $\mathrm{NH}_{4}^{+}$fluxes $(r=-$ $0.83, p<0.01$ ), which indicates that the greater the consumption of oxygen during mineralization of $\mathrm{OM}$, the greater the release of $\mathrm{NH}_{4}{ }^{+}$to the water column (Berelson et al. 2003).

Table 2 Pearson's correlation coefficients for relationships between variables measured in bottom water and sediment. Values in bold are significant at $p<0.05$; values in italics are significant at $p<0.01$. The number of observations ranged from 8 to 16 . Temp temperature, bot bottom, sed sediment.

\begin{tabular}{|c|c|c|c|c|c|c|c|c|c|c|}
\hline & $\begin{array}{l}\mathrm{DO} \\
\text { flux }\end{array}$ & $\begin{array}{l}\mathrm{PO}_{4}{ }^{3-} \\
\text { flux }\end{array}$ & $\begin{array}{l}\text { Si } \\
\text { flux }\end{array}$ & $\begin{array}{l}\mathrm{NH}_{4}{ }^{+} \\
\text {flux }\end{array}$ & $\begin{array}{l}\mathrm{NO}_{3}^{-} \\
\text {flux }\end{array}$ & $\begin{array}{c}\text { Temp } \\
\text { bot }\end{array}$ & $\begin{array}{l}\text { OM } \\
\text { sed }\end{array}$ & $\begin{array}{l}\text { Eh } \\
\text { sed }\end{array}$ & $\begin{array}{l}\text { TP } \\
\text { sed }\end{array}$ & $\begin{array}{r}\mathrm{NO}_{3} \\
\text { bot }\end{array}$ \\
\hline DO flux & 1.00 & & & & & & & & & \\
\hline $\mathrm{PO}_{4}{ }^{3-}$ flux & -0.56 & 1.00 & & & & & & & & \\
\hline Si flux & -0.17 & -0.27 & 1.00 & & & & & & & \\
\hline $\mathrm{NH}_{4}{ }^{+}$flux & -0.83 & 0.56 & $\begin{array}{c}- \\
0.11\end{array}$ & 1.00 & & & & & & \\
\hline $\mathrm{NO}_{3}{ }^{-}$flux & 0.13 & -0.71 & 0.24 & -0.08 & 1.00 & & & & & \\
\hline Temp bottom & -0.32 & -0.25 & 0.59 & 0.39 & 0.51 & 1.00 & & & & \\
\hline OM sediment & -0.60 & 0.24 & 0.34 & 0.70 & 0.10 & 0.71 & 1.00 & & & \\
\hline Eh sediment & 0.67 & -0.59 & $\begin{array}{c}- \\
0.44\end{array}$ & -0.61 & 0.30 & -0.53 & $\overline{-}$ & 1.00 & & \\
\hline TP sediment & -0.72 & 0.83 & 0.00 & 0.77 & -0.49 & 0.21 & 0.69 & $\begin{array}{c}- \\
0.79\end{array}$ & 1.00 & \\
\hline $\mathrm{NO}_{3}{ }^{-}$bottom & -0.13 & 0.67 & $\begin{array}{c}- \\
0.46\end{array}$ & 0.10 & -0.92 & -0.63 & $\begin{array}{c}- \\
0.19\end{array}$ & $\begin{array}{c}- \\
0.09\end{array}$ & 0.46 & 1.00 \\
\hline
\end{tabular}


Below the cages, the flux of ammonium from the sediment to the water column was greater than at the control station, increasing by $11 \mathrm{mmol}$ $\mathrm{m}^{-2}$ day ${ }^{-1}$ at the start of summer. $\mathrm{NH}_{4}^{+}$fluxes at the fish farm were greater in early summer $\left(12.7 \pm 1.0 \mathrm{mmol} \mathrm{m}{ }^{-2}\right.$ day $\left.^{-1}\right)$, followed by autumn and then spring (see Fig. 2b). This correlated with the OM content in the sediment $(r=0.70, p<0.01)$. Ferrón et al. (2009) observed $\mathrm{NH}_{4}{ }^{+}$fluxes of 5 to $20 \mathrm{mmol}$ $\mathrm{m}^{-2}$ day $^{-1}$, and Nizzoli et al. (2007) found values ranging from 10 to $57 \mathrm{mmol}$ $\mathrm{m}^{-2}$ day ${ }^{-1}$. Both studies also found that the greatest fluxes occurred in the summer, when temperatures and aquaculture activity were higher. Especially noteworthy was the fact that for three of the four sampling campaigns, significant differences in $\mathrm{NH}_{4}{ }^{+}$fluxes were observed between the fish farm and control station.

$\mathrm{PO}_{4}{ }^{3-}$ fluxes were higher under the cages than at the control station, rising from $0.44 \mathrm{mmol} \mathrm{m}^{-2}$ day ${ }^{-1}$ in winter to $0.84 \mathrm{mmol} \mathrm{m}^{-2}$ day $^{-1}$ in autumn, due to the higher content of TP in the sediment ( $r=0.83, p<0.01) . \mathrm{PO}_{4}{ }^{3-}$ fluxes were correlated (see Table 2) to $\mathrm{NH}_{4}^{+}(r=0.57, p<0.05)$ and DO fluxes $(r=-$ 0.56, $p<0.05)$. This can be explained by the decomposition of OM, which involves an uptake of DO to produce $\mathrm{NH}_{4}{ }^{+}$and $\mathrm{PO}_{4}{ }^{3-}$. Nevertheless, there was no direct relationship between this and OM content, probably due to the fact that the uppermost layer of the sediment, which was probably well oxygenated, retained $\mathrm{PO}_{4}{ }^{3-}$. We also obtained an interesting correlation between $\mathrm{PO}_{4}{ }^{3-}$ flux and Eh $(r=-0.59, p<0.05)$, which was attributable to the fact that P may be released under anaerobic conditions (Rodríguez 1999), such as those observed in below the superficial sediment layer. Ferrón et al. (2009) observed flux data for $\mathrm{PO}_{4}{ }^{3-}$ similar to those seen in this study.

Nitrate fluxes were consistently negative; $\mathrm{NO}_{3}{ }^{-}$in the water column was consumed by the sediment due to benthic denitrification occurring in the suboxic and anoxic sediment layers, where $\mathrm{NO}_{3}{ }^{-}$acts as a terminal acceptor 
of electrons (Herbert 1999). In samples taken in the autumn, winter and spring, $\mathrm{NO}_{3}{ }^{-}$fluxes were found to be more negative at the fish farm than at the control station; $\mathrm{NO}_{3}{ }^{-}$consumption is as much as $1.2 \mathrm{mmol} \mathrm{m}^{-2}$ day $^{-1}$ higher on the fish farm compared to the control, despite the fact that significant differences were found in autumn only. These differences may be explained by the higher concentrations of OM under the cages where suboxic/anoxic zones of the sediments are closer to the surface, favouring increased benthic denitrification. Greater negative fluxes were observed in autumn and winter under the cages, co-occurring with the higher concentrations of $\mathrm{NO}_{3}{ }^{-}$in the bottom water (see Table 1). The correlation between $\mathrm{NO}_{3}{ }^{-}$fluxes and initial concentrations of $\mathrm{NO}_{3}{ }^{-}$in the bottom waters was $r=-0.92 \quad(p<0.01)$. Previous studies have shown a clear negative relationship between $\mathrm{NO}_{3}{ }^{-}$flux and $\mathrm{NO}_{3}{ }^{-}$concentration in bottom water (Sakamaki et al. 2006). The high concentrations of $\mathrm{NO}_{3}{ }^{-}$in the bottom waters increase its flux into sediments, increasing $\mathrm{NO}_{3}{ }^{-}$concentrations in interstitial water, which in turn favours bacterial nitrate respiration. As the concentration of $\mathrm{NO}_{3}{ }^{-}$increases, $\mathrm{NO}_{3}{ }^{-}$is reduced to $\mathrm{N}_{2} / \mathrm{N}_{2} \mathrm{O}$ and $\mathrm{N}$ is lost from the system due to denitrification (Herbert 1999).

The highest and most positive Si fluxes were observed in spring and early summer due to the increase in Si dissolution rates caused by the higher temperatures (Cermelj et al. 2001). The correlation between Si fluxes and temperature (see Table 2) was $0.59(p<0.05)$. Fish farm activity does not seem to affect Si fluxes as OM from the fish farm had a low Si content. Other studies (e.g. Freitas et al. 2008) also indicate that Si fluxes are not significantly influenced by aquaculture activities and they also find positive flows, similar to those seen in Ferrón et al. (2009).

To determine the implications that these fluxes might have for the water column, it is first necessary to quantify their importance to primary 
production. Morán and Estrada (2005) studied the north-western basin of the Mediterranean Sea and observed that total phytoplankton biomass was closely correlated with primary production and proposed a linear regression model which integrated daily rates of primary production $\left(\mathrm{PP}_{\text {int }}\right)$ with integrated values of chl- $a$ (chl- $\left.a_{\text {int }}\right)$. Since we had data from all our sampling campaigns for chl- $a$ taken every $2 \mathrm{~m}$ depth in the water column, we were able to calculate the average chl- $a_{\text {int }}$ for both the control and fish farm. In both areas, the average chl- $a_{\text {int }}$ was similar, at around $7.2 \mathrm{mg} \mathrm{m}^{-2}$. Subsequently, we used the relation postulated by Morán and Estrada (2005) to estimate the integrated daily production, which was $139 \mathrm{mg} \mathrm{C} \mathrm{m}^{-2}$ day $^{-1}$ (ca. $12 \mathrm{mmol} \mathrm{C}$ $\mathrm{m}^{-2}$ day $\left.^{-1}\right)$. Assuming nutrient utilization ratios approaching Redfield and no nitrogen fixation (Redfield et al. 1963; Niencheski and Jahnke 2002), phytoplankton would require ca. $2 \mathrm{mmol} \mathrm{N} \mathrm{m}^{-2}$ day $^{-1}, 0.1 \mathrm{mmol} \mathrm{P} \mathrm{m}^{-2}$ day $^{-1}$ and 2 mmol Si m${ }^{-2}$ day $^{-1}$. We calculated average $\mathrm{N}$ benthic flux from the sum of the fluxes of $\mathrm{NH}_{4}^{+}, \mathrm{NO}_{3}^{-}$and $\mathrm{NO}_{2}^{-}$(data not shown) for both the control and fish farm, giving 1.3 and $4.4 \mathrm{mmol} \mathrm{N} \mathrm{m}^{-2}$ day $^{-1}$, respectively. At the control station, nearly three quarters of phytoplankton $\mathrm{N}$ requirements can be met by benthic $\mathrm{N}$ fluxes, whereas at the fish farm, the benthic fluxes are 2.5 times higher than these requirements. Average $\mathrm{P}$ benthic fluxes were 0.1 mmol $\mathrm{P} \mathrm{m}^{-2}$ day $^{-1}$ for the control and $0.8 \mathrm{mmol} \mathrm{P} \mathrm{m}^{-2}$ day $^{-1}$ for the fish farm, which indicates that phytoplankton $\mathrm{P}$ requirements are met by benthic fluxes in both cases, even though on the fish farm, they are eight times higher. The average benthic $\mathrm{Si}$ fluxes at the control and fish farm were similar at approximately $1 \mathrm{mmol} \mathrm{Si} \mathrm{m} \mathrm{day}^{-1}$, which is half of the diatom $\mathrm{Si}$ requirements. The above results show that the fish farm has a far higher availability of $\mathrm{P}$ and $\mathrm{N}$ than the control, while the contribution of Si by the sediment is the same in both locations. On the fish farm, these differences might lead to a modification in the structure of the phytoplankton community and promote the growth of species which do not use $\mathrm{Si}$ as a nutrient. 
However, the greater availability of $\mathrm{N}$ and $\mathrm{P}$ on the fish farm was not reflected in differences in $\mathrm{PP}_{\text {int }}$, which was similar in both zones, at around $7.2 \mathrm{mg} \mathrm{m}^{-2}$. This indicates that there is a high amount of dilution in the zone as a consequence of the high hydrodynamic behaviour of open seawater, making it impossible to detect differences in the phytoplankton biomass. This corroborates the observations made for similar fish farms in the Mediterranean by Pitta et al. (1999) and Sarà et al. (2006).

\section{Conclusions}

Floating cage aquaculture in the marine environment generates an accumulation of $\mathrm{OM}$ in sediments, which reaches peak values in summer. The variations in the accumulation of OM occurring on fish farms are very closely linked to the metabolic activity of the fish bred on farms, and this depends on the water temperature. As a result, sediments undergo biochemical changes which primarily affect oxygen consumption, release of $\mathrm{NH}_{4}{ }^{+}$and $\mathrm{PO}_{4}{ }^{3-}$ and $\mathrm{NO}_{3}{ }^{-}$consumption by the sediment. However, Si fluxes seem unaffected by fish farm activity since the contribution of $\mathrm{Si}$ by fish farms is currently negligible. In the future, if the use of fish feed of vegetable origin instead of fish meal becomes more widespread, it will become necessary to reassess the Si contributed by fish farm activity.

Our results for benthic flux in situ are the first obtained for caged fish farms in the Mediterranean and they show that sediments can play an important role in nutrient cycling. Furthermore, benthic fluxes can have an important influence the concentrations of oxygen and nutrients in the water column; oxygen consumption is as much as $42 \mathrm{mmol} \mathrm{m}^{-2}$ day $^{-1}$ higher on the fish farm compared to the control site. Although no important consequences are detected in the water column, the accumulation of organic waste and oxygen concentrations in the water near the bottom will need constant monitoring owing to the hydrodynamic features of such locations. The flux 
which has the greatest importance relative to the requirements of the primary producers is $\mathrm{PO}_{4}{ }^{3-}$. However, the system does not seem to be affected by the presence of such high fluxes, possibly because of the dilution due to the hydrodynamic behaviour of open seawater. In the future, it will be necessary to consider the broader (in time and space) repercussions that the input of nutrients has on the ecosystem as a whole.

\section{Acknowledgments}

We would like to thank the Caja del Mediterráneo for a predoctoral fellowship fund for this research and Antonio Asunción Acuigroup Maremar manager for the facilities and support in conducting the study. The translation of this paper was funded by the Universidad Politécnica de Valencia, Spain. We are grateful for the valuable comments of the anonymous reviewers on previous versions of the manuscript.

\section{References}

APHA, AWWA, and WEF (2005) Standard methods for the examination of water wastewater 21th edn. American Public Health Association, Washington

Aksu M, Kocatas A (2007) Environmental effects of the three fish farms in Izmir Bay (Aegean Sea-Turkey) on water column and sediment. Rapport du 38e Congrés de la Commission Internationale Pour L'exploration Scientifique de la Mer Méditerranée 38, 414

Aminot A, Chaussepied M (1983) Manuel des analyses chimiques en milieu marin. Centre National pour l'Explotation des Oceans, Brest

Arocena R, Conde D (1999) Sedimento. Métodos en ecología de aguas continentales. 40-52. Universidad de la República, Montevideo

Asociación Empresarial de Productores de Cultivos Marinas (APROMAR) (2010) La Acuicultura Marina de Peces en España. pp 69 
Baumgarten MGZ, Rocha JM, Niencheski LFH (1996) Manual de análises em oceanografia química, Rio Grande

Belias C, Dassenakis M, Scoullos M (2007) Study of the N, P and Si fluxes between fish farm sediment and seawater. Results of simulation experiments employing a benthic chamber under various redox conditions. Mar Chem 103:266-275

Berelson WM, McManus J, Coale KH, Johnson KS, Burdige D, Kilgore T, Colodner D, Chavez F, Kudela R, Boucher J (2003) A time series of benthic flux measurements from Monterey Bay, CA. Cont Shelf Res 23:457-481

Black KD, McDougall N (2002) Hydrography of four Mediterranean marine cage sites. J Appl Ichthyol 18:129-133

Borja A, Rodríguez JG, Black K, Bodoy A, Emblow C, Fernandes TF, Forte J, Karakassis I, Muxika I, Nickell TD, Papageorgiou N, Pranovi F, Sevastou K, Tomassetti P, Angel D (2009) Assessing the suitability of a range of benthic indices in the evaluation of environmental impact of fin and shellfish aquaculture located in sites across Europe. Aquaculture 293:231-240

Cermelj B, Ogrinc N, Faganeli J (2001) Anoxic mineralization of biogenic debris in near-shore marine sediments (Gulf of Trieste, northern Adriatic). Sci Total Environ 266:143-152

Dell’Anno A, Mei ML, Pusceddu A, Danovaro R (2002) Assessing the trophic state and eutrophication of coastal marine systems: a new approach based on the biochemical composition of sediment organic matter. Mar Pollut Bull 44:611-622

Dosdat A (2001) Environmental impact of aquaculture in the Mediterranean: nutritional and feeding aspects. Environmental Impact Assessment of Mediterranean Aquaculture Farms. Cah Options Méditerr CIHEAMFAO 55:23-36 
Ferrón S, Ortega T, Forja JM (2009) Benthic fluxes in a tidal salt marsh creek by fish farm activities: Río San Pedro (Bay of Cádiz, SW Spain). Mar Chem 113:50-62

Freitas U, Niencheski LFH, Zarzur S, Manzolli RP, Vieira JPP, Rosa LC (2008) Influência de um cultivo de camaraô sobre o metabolismo béntico e a qualidade da agua. Rev Bras Eng Agríc Ambient 12:293301

Hall POJ, Holby O, Kollberg S, Samuelsson MO (1992) Chemical fluxes and mass balances in a marine fish cage farm: IV. Nitrogen. Mar Ecol Prog Ser 89:81-91

Hargrave B (2005) Environmental Effects of Marine Finfish Aquaculture.

The Handbook of Environmental. Chemistry, vol. 5, Part M. Springer, Berlin

Hargrave BT, Phillips GA, Doucette LI, White MJ, Milligan TG, Wildish DJ, Cranston RE (1997) Assessing benthic impacts of organic enrichment from marine aquaculture. Water Air Soil Poll 99:641-650

Heilskov AC, Holmer M (2001) Effects of benthic fauna on organic matter mineralization in fish-farm sediments: importance of size and abundance. ICES J Mar Sci 58:427-434

Herbert RA (1999) Nitrogen cycling in coastal marine ecosystems. FEMS Microbiol Rev 23:563-590

Holby O, Hall POJ (1991) Chemical fluxes and mass balances in a marine fish cage farm. 11. Phosphorus. Mar Ecol Prog Ser 70:263-272

Holby O, Hall POJ (1994) Chemical fluxes and mass balances in a marine fish cage farm. III. Silicon. Aquaculture 120:305-318

Jackson C, Preston N, Thompson PJ (2004) Intake and discharge nutrient loads at three intensive shrimp farms. Aquaculture Res 35:1053-1061 
Karakassis I, Tsapakis M, Hatziyanni E (1998) Seasonal variability in sediment profiles beneath fish farm cages in the Mediterranean. Mar Ecol Prog Ser 162:243-252

Kaymakci A, Aksu M, Egemen O (2010) Impacts of the fish farms on the water column nutrient concentrations and accumulation of heavy metals in the sediments in the eastern Aegean Sea (Turkey). Environ Monit Assess 162:439-451

Lorenti M, De Falco G (2004) Measurements and characterization of abiotic variables. In: Gambi MC, Diappiano M (ed) Mediterranean Marine Benthos: A Manual of Methods for its Sampling and Study, Societa Italiana di Biologia Marina, Genova, pp 1-37

Maldonado M, Carmona MC, Echeverría Y, Riesgo A (2005) The environmental impact of Mediterranean cage fish farms at semiexposed locations: Does it need a re-assessment? Helgoland Mar Res 59:121-135

Mantzavrakos E, Kornaros M, Lyberatos G, Kaspiris P (2007) Impacts of a marine fish farm in Argolikos Gulf (Greece) on the water column and the sediment. Desalination 210:110-124

Mazzola A, Mirto S, La Rosa T, Fabiano M, Danovaro R (2000) Fishfarming effects on benthic community structure in coastal sediments: Analysis of meiofaunal recovery. ICES J Mar Sci 57:1454-1461

Molina L, Vergara JM (2005) Impacto ambiental de jaulas flotantes: estado actual de conocimientos y conclusiones prácticas. Bol Inst Esp Oceanogr 21:75-81

Morán XAG, Estrada M (2005) Winter pelagic photosynthesis in the NW Mediterranean Deep-Sea. Research I 52:1806-1822

Neofitou N, Klaoudatos S (2008) Effect of fish farming on the water column nutrient concentration in a semi-enclosed gulf of the Eastern Mediterranean. Aquac Res 39:482-490 
Niencheski LF, Jahnke RA (2002) Benthic respiration and inorganic nutrient fluxes in the estuarine región of Patos Lagoon (Brazil). Aquat Geochem 8:135-152

Nizzoli D, Bartoli M, Viaroli P (2007) Oxygen and ammonium dynamics during a farming cycle of the bivalve Tapes philippinarum. Hydrobiologia 587:25-36

Pergent-Martini C, Boudouresque CF, Pasqualini V, Pergent G (2006) Impact of fish farming facilities on Posidonia oceanica meadows: a review. Mar Ecol 27:310-319

Pitta P, Karakassis I, Tsapakis M, Zivanovic S (1999) Natural versus mariculture induced variability in nutrients and plankton in the Eastern Mediterranean. Hydrobiologia 391:181-194

Redfield AC, Ketchum BH, Richards FA (1963) The influence of organisms on the composition of seawater. In: Hill MN (ed) The Sea. Vol 2, Interscience Publishers, New York

Riise JC, Roos N (1997) Benthic metabolism and the effects of bioturbation in a fertilized polyculture fish pond in northeast Thailand. Aquaculture $150: 45-62$

Rodríguez J (1999). Ecología. Ed.Pirámide.411 pp

Sakamaki T, Nishimura O, Sudo R (2006) Tidal time-scale variation in nutrient flux across the sediment-water interface of an estuarine tidal flat. Estuar Coast Shelf Sci 67:653-663

Sarà G, Scilipoti D, Milazzo M, Modica A (2006) Use of stable isotopes to investigate dispersal of waste from fish farms as a function of hydrodynamics. Mar Ecol Prog Ser 313:261-270

Shepard FP (1954) Nomenclature based on sand-silt-clay relations. J Sediment Petrol 24:151-158 
Siokou-Frangou I, Christaki U, Mazzocchi MG, Montresor M, Ribera d'Alcalá M, Vaqué D, Zingone A (2010) Plankton in the open Mediterranean Sea: a review. BG 7:1543-1586

Warnken KW, Gill, GA, Lehman R, Dellapenna, T, Allison MA (2002) The effects of shrimp trawling on sediment oxygen demand and the release of trace metals and nutrients from estuarine sediments. Estuar Coast Shelf Sci 57:25-42

Yucel-Gier G, Kucuksezgin F, Kocak F (2007) Effects of fish farming on nutrients and benthic community structure in the Eastern Aegean (Turkey). Aquac Res 38:256-267 